\title{
Okul Öncesi Eğitim Kurumlarına Devam Eden Çocukların Sosyal Yetkinlik Davranışlarının İncelenmesi*
}

Nur Uygun $^{* * 1}$ ve İshak Kozikoğlu ${ }^{2}$

Öz

Anahtar Sözcükler

Okul öncesi eğitime devam eden çocuklar

Sosyal yetkinlik davranışları

Okul öncesi eğitimi

Makale Hakkında

Gönderim Tarihi

12 Şubat 2019

Kabul Tarihi

16 Temmuz 2019

Makale Türi

Araştırma Makalesi yetkinlik, anksiyete-içedönüklük ve kızgınlık-saldırganlık davranışlarının yaş ve aile gelir düzeyi değişkenlerine göre anlamlı düzeyde farklılaşmadı̆̆ 1 sonucuna ulaşılmıştır. Öğretmenlerin problem davranışları sıklıkla sergileyen çocukları tespit edip çocukların sosyal gelişimlerini olumlu yönde etkileyecek etkinliklere daha sık yer vermeleri önerilebilir.

\section{Examining Social Competence Behaviors of Children Attending Preschool Education Institutions*}

\section{Abstract}

The aim of this study is to determine social competence behaviors of children attending preschool education institutions in 2017-2018 academic year. In this study, descriptive survey model was used. The sample consists of 521 children determined by stratified sampling method. In this study, Social Competence and Behavior Assessment-30 Scale was used to determine the social competence behaviors of children. In data analysis, descriptive statistics and differential statistics were used. As a result of study, it was concluded that children often exhibit social competence behaviors, and hardly exhibit anxiety-introversion and anger-aggression behaviors. The social competence scores of girls are higher than boys; the social competence behaviors of the children increase as the level of parental education increases; as the number of siblings increase, children's anxiety-introverted behaviors increase; but children's social competence, anxiety-introverted and anger-aggression behaviors do not differ significantly according to age and family's income level. It is suggested that teachers identify children who exhibit frequent problem behaviors and conduct more activities to affect the social development of children.
Keywords

Preschoolers

Social competence

behaviors

Preschool education

Article Info

Received

February 12, 2019

Accepted

July 16, 2019

Article Type

Research Paper

Atıf: Uygun, N. ve Kozikoğlu, İ. (2019). Okul öncesi eğitim kurumlarına devam eden çocukların sosyal yetkinlik davranışlarının incelenmesi. Ege Eğitim Dergisi, 20(1), 305-321. doi: 10.12984/egeefd.526276

\footnotetext{
* Bu çalışma, Nur Uygun tarafından Dr. Öğr. Üyesi İshak Kozikoğlu danışmanlığında yürütülen yüksek lisans tezinden üretilmiştir. [This study was produced from master thesis prepared by Nur Uygun under the supervision of Assist. Prof. İshak Kozikoğlu] *** Sorumlu Yazar/Corresponding Author

1 (D) Van Yüzüncü Y1l Üniversitesi, Eğitim Fakültesi, Eğitim Bilimleri Bölümü, Türkiye, nuruygun.13@ gmail.com

2 (D) Van Yüzüncü Y1l Üniversitesi, Eğitim Fakültesi, Eğitim Bilimleri Bölümü, Türkiye, $\underline{\text { ishakkozikoglu@yyu.edu.tr }}$
} 


\section{Extended Abstract}

\section{Introduction}

Socialization is the most important feature that differentiates man from other living things (Dinçer, 2011). Children, who are members of the family and society from the moment of their birth, are in an effort to adapt to the society in which they live (Çağdaş \& Seçer, 2002). It is of great importance to have various social skills as well as cognitive skills necessary to minimize the adversities of the developing and changing age and to realize its positive aspects effectively. Social skills, defined as the ability to act in accordance with the environment, are important in establishing effective communication among people and reaching social goals (Avcioğlu, 2003).

Although the first social experiences take place in the family, the child continuously observes the teacher as a model after beginning the school. The attitudes of the teacher and the communication with the child, such as parental attitudes, have a significant impact on the child's behavior. The teacher's attention to the individual differences of the child will enable the child to realize his/her abilities and to feel valuable (Çağdaş \& Seçer, 2002; Yavuzer, 1985). Furthermore, the teacher's social behaviors such as sharing, cooperating in the classroom environment, and communicating effectively with the child positively affect the social skills development of the child.

Enriching the opportunities offered by the family, preschool education institutions provide children with the necessary environment for their physical, cognitive and social development (Uğur, 1998). Therefore, the social skills of the child, who have the opportunity to experiment with many peers in preschool education institutions under the supervision of the teacher, develop positively. Social competence behaviors can be grouped into three categories that are social competence, anger-aggression behaviors and anxiety-introversion behaviors. The aim of this study is to determine the social competence behaviors of children attending preschool education institutions affiliated with the Ministry of National Education during 2017-2018 academic year.

Social skills are one of the skills that a human being needs to gain in order to adapt to the changing world at every age. Individuals who are aware of their abilities and skills and who have high self-esteem and positive selfconcept are expected to establish healthy social relationships with their peers and the society. In order to have social skills as an indicator of social competence, the individual needs to acquire these skills in the pre-school period, which is a critical period in all areas of development. The lack of adequate social development in the preschool period causes the child to have low social competence (Haktanır, 2011). This situation causes both communication problems and behavior problems in both childhood and adulthood. Therefore, it is necessary to determine the social competence behaviors of children attending pre-school education institutions to take necessary measures and address any behavior problems. Thus, it is believed that this study, which is based on the teachers' views on social competence behaviors of children according to various variables, will contribute to the related literature.

\section{Method}

In this study, descriptive survey model was used. The target population of the study is composed of 12.183 children who are attending preschool education institutions affiliated with the Ministry of National Education in the central districts of Van province, that are Ipekyolu, Tuşba and Edremit, during 2017-2018 academic year. The sample of the study consists of 521 children that were determined by stratified sampling method.

In this study, Social Competence and Behavior Assessment-30 Scale was used to determine social competence behaviors of children. In the analysis of research data, descriptive and differential statistics were used.

\section{Findings}

As a result of study, it was concluded that children often exhibit social competence behaviors, and hardly exhibit anxiety-introversion and anger-aggression behaviors. The social competence scores of girls are higher than boys; the social competence behaviors of the children increase as the level of parental education increases while anxiety-aggression and anger-aggression behaviors decrease; as the number of siblings increase, children's anxiety-introverted behaviors increase; but children's social competence, anxiety-introverted and angeraggression behaviors do not differ significantly according to age and family's income level. 


\section{Discussion and Conclusion}

In the existing literature, it is stated that children with social competence recognize and control themselves and their emotions, establish healthy communication with their surroundings, and have a positive sense concerning themselves (Çorapçı, Aksan, Arslan-Yalçın, \& Yağmurlu, 2010; Çorbacı, 2008; Haktanır, 2011). When the results of this study are evaluated, it can be said that the children attending pre-school education institutions can express themselves and their emotions, they can communicate with their peers in a healthy way, in short, they have social skills to be gained in pre-school period. Based on the results of this study, the following suggestions are presented below:

a) It was found that children exhibited social competence behaviors at a high level, but boys exhibited anger-aggression behaviors more than girls. Considering that preschool education is critical for all areas of development of the child, teachers have a great responsibility. It can be suggested that teachers identify children who exhibit problem behaviors and conduct more activities to affect the social development of children.

b) It was determined that the social competence behaviors of the children increased as the education level of the parents increased. In order for parents to communicate effectively with their children, it may be advisable to open courses in Public Education Centers or to organize seminars for parents. In addition, increasing parent participation in preschool education institutions and the cooperation of the parents with the child's teacher can ensure that the social skills gained at school are also modeled at home.

c) The reasons for showing the anger and aggression behaviors can be examined in detail by conducting a study with boys.

d) Studies can be conducted examining the impact of the preschool education program or teachers' communication with the child on the social competence behaviors of the children. 


\section{Giriş}

Bireyin yaşamındaki en önemli süreçlerinden olan sosyalleşme, insanı diğer canlılardan ayıran en temel özelliktir (Dinçer, 2011). Doğduğu andan itibaren ailenin ve toplumun bir üyesi olan çocuk, tüm yaşamı boyunca içinde bulunduğu topluma uyum sağlama çabası içindedir (Çağdaş ve Seçer, 2002). Gelişen ve değişen çağın olumsuzluklarını en aza indirgemek ve olumlu yönlerini de etkin olarak hayata geçirebilmek için gerekli olan bilişsel becerilerin yanı sıra çeşitli sosyal becerilere de sahip olmak oldukça önemlidir. İçinde bulunulan ortama uygun davranma becerisi olarak tanımlanan sosyal beceriler, kişiler arası etkili iletişim kurmada ve toplumsal hedeflere ulaşmada önemlidir (Avcıŏlu, 2003).

Çocuğun arkadaşlarından ve çevresindeki yetişkinlerden aldığı geri bildirimler, içinde bulunduğu sosyal ortamlar, öğrenme yaşantıları sosyal becerilerin kazanılmasında önemli unsurlardır (Dinçer, 2011). İyi bir gözlemci olan çocuklar, ebeveynlerinin ve arkadaşlarının kendisiyle ve başkalarıyla etkileşimini gözlerler (Çağdaş ve Seçer, 2011). Çocuk sosyal deneyimlerini ilk kez aile ortamında elde etmektedir. Gözlemleme ve taklit etme davranışlarını sergileyen çocuk ilk olarak anne-babasını kendisine bir model olarak seçer. Ebeveynin çocuğun olumlu veya olumsuz davranışlarına gösterdikleri tepkileri, çocukla kurduğu iletişim çocuğun kazandığı ilk sosyal becerilerini şekillendirmektedir (Çağdaş ve Seçer, 2011). Tutarlı ebeveyn tutumuyla karşılaşan çocuk, davranışlarını değerlendirip doğru ve yanlış davranışlarını ayırt edebilecektir. Sevgi ve güveni önemseyen bir aile ortamında büyüyen çocuk çevresindeki insanları sevmeyi, onlarla etkili iletişim kurabilmeyi öğrenir (Yalçın, 2010). Annenin çocukla sevgi bağı kurması, çocuğun yeme, temizlik, uyku gibi temel ihtiyaçlarını karşılarken çocuğa sevgi ve ilgiyle yaklaşması, çocuğun çevresiyle olumlu sosyal ilişkiler kurmasına temel oluşturmakta ve sosyal gelişimini olumlu yönde etkilemektedir (Akbaş ve Budak, 2011). Ailenin yanı sıra, çocuğun dış dünyayı ve kendi iç dünyasını anlamasında yani bireyselleşmesi ve toplumsallaşmasında akranlarıyla kurduğu etkileşim oldukça önemlidir. Çocuk, işbirliği içinde oynama, yardımlaşma, tartı̧ma, kaçma, kovalama, paylaşma, sıra bekleme, kabul edilme, reddedilme, kurallara uyma, bir işi başlatma ve devam ettirme gibi birçok deneyimi arkadaşlarıyla etkileşim içindeyken kazanmaktadır (Aydın, 2004; Keçecioğu, 2015;).

İlk sosyal deneyimler ailede yaşansa da çocuk okula başladıktan sonra öğretmenini model almakta ve sürekli gözlemlemektedir. Ebeveyn tutumu gibi öğretmenin tutumu ve çocukla iletişimi de çocuğun davranışlarında önemli etkiye sahiptir. Öğretmenin çocuğun bireysel farklılıklarına dikkat etmesi çocuğun yeteneklerini fark etmesini, kendini değerli hissetmesini sağlayacaktır (Çağdaş ve Seçer, 2002; Yavuzer, 1985). Ayrıca, öğretmenin sınıf ortamında yardımlaşma, paylaşma, empati kurma, işbirliği içinde olma gibi sosyal davranışları sergilemesi, çocukla etkili iletişim kurması, çocuğun sosyal beceri gelişimini olumlu yönde etkilemektedir.

Okul öncesi eğitimin önemli amaçlarından biri çocuklara sosyal becerileri kazandırmaktır. Bu amaç doğrultusunda öğretmen, çeşitli öğrenme ortamlarını oluşturarak çocuğun daha bağımsız ve girişken olmasını desteklemektedir (Zembat, 2013). Aile tarafından sunulan imkânları zenginleştiren okul öncesi eğitim kurumları, çocuklara hem fiziksel hem de bilişsel ve sosyal gelişimleri için gerekli ortamı sağlar (Uğur, 1998). Dolayısıyla, okul öncesi eğitim kurumlarında öğretmenin gözetiminde ailede kazandığı becerileri birçok akranıyla deneme firsatı bulan çocuğun sosyal becerileri olumlu yönde gelişmektedir. Sosyal yetkinlik davranışları; sosyal yetkinlik, saldırganlık ve anksiyete-içedönüklük davranışları olmak üzere üç grupta ele alınabilir.

Altay ve Güre (2012) sosyal yetkinliği, çocuğun içinde bulunduğu ortamda sergilemiş olduğu davranışlar olarak tanımlamaktadır. Çocuğun sosyal yetkinliğe sahip olması, sosyal becerilerinin gelişmesiyle doğru orantılıdır. Çocukların arkadaşlarıyla ve yetişkinlerle etkili iletişim kurmaları, bulundukları sosyal ortama göre duygularını ve davranışlarını düzenlemeleri, kendilerini ifade edebilmeleri sosyal yetkinliğin önemli göstergelerindendir (Çorapçı, Aksan, Yalçın ve Yağmurlu, 2010). Bireyin kendi duygularını, davranışlarını ve sosyal ilişkilerini yönetebilmesi olarak da tanımlanan sosyal yetkinliğin yüksek olması için atılganlık becerilerinin gelişmiş olması gerekir. Kişiler arası nitelikli etkileşimin oluşmasını sağlayan atılganlık becerileri kendini tanıtma, isteklerini ve rahatsız olduğu durumları ifade edebilme, haklarını koruyabilme, empati kurma gibi davranışları içermektedir (Ünal, 2007).

Saldırganlık, zarar vermek amacıyla bir kişiye veya nesneye karşı uygulanan davranışlar olarak tanımlanmaktadır. Bireyin kendi düşünce ve istekleri dışındaki her şeye karşı direnme ve zorla karşısındakine kabul ettirmeye çalışması da saldırgan davranışlardandır (Gürüz, 2005; Yasankul, 2007). Çocuklarda görülen saldırganlık, öfke ve kızgınlık gibi olumsuz duygularını yönetemeyip davranışa dönüştürerek çevresine az ya da çok zarar verme durumudur. Çocuğun saldırgan olarak nitelenmesi için itme, kovalama, geçimsizlik ve kavga gibi davranışları tüm sosyal ortamlarda sürekli sergilemesi ve şiddet içerikli olması gerekir (Özdemir, 2014).

Anksiyete-içe dönüklük davranışları, grup içinde çekingenlik, kendini mutsuz hissetme, depresif duygu durumları olarak tanımlanmaktadır. Bu davranışları gösteren bireyler, grup içinde kendi fikirlerini, duygu ve düşüncelerini ifade etmede zorlanırlar. Aşağılık duygusu içinde oldukları için başkalarının kendisi yerine karar vermesine tepki göstermezler. Çekingen insanlar çevresi tarafından sevilmediklerini düşünürler, kimseyle yakın 
ilişkiler kuramazlar. Mükemmeliyetçi anlayışa sahip oldukları için sürekli kendilerini eleştirirler ve bulunduğu ortamda benimsenen fikrin dışında düşüncelerini, isteklerini ifade edemezler. Kişinin sürekli başkaları tarafindan eleştirilme korkusu, utanç ve gülünç duruma düşme düşüncesi çekingenlik davranışlarını göstermesine neden olur. Genellikle sosyal kaygıya sahip olan çocuklar, çekingen davranışlar gösterirler (Baltaş, 2002).

Etkili iletişim kurma becerileri çocukluk döneminde şekillenmeye başladığı için sosyal becerilerin kazanılmasında okul öncesi dönem kritik öneme sahiptir. Çocuğun kendini tanıması, duygularını kontrol edip ifade edebilmesi, yakın çevresi ve uzak çevresiyle sağlıklı iletişim kurabilmesi okul öncesi dönemde gerçekleşmesi beklenen sosyal becerilerdir (Kuyucu, 2013; Çorapçı ve diğ., 2010). Dolayısıyla, okul öncesi eğitim kurumlarına devam eden çocukların sergiledikleri sosyal yetkinlik davranışlarının belirlenmesine ihtiyaç duyulmaktadır. Alanyazındaki benzer çalışmalar (Alisinanoğlu ve Kesicioğlu, 2010; Altay ve Güre, 2012; Karaca, Gündüz ve Aral, 2011; Karg1 ve Erkan, 2004; Nalbant, 2016; Ogelman ve Topaloğlu, 2014) incelendiğinde, çalışmalarda verilerin sınırlı bir örneklem grubuyla ebeveyn ve öğretmen görüşleri doğrultusunda toplandığı görülmektedir. $\mathrm{Bu}$ çalışma daha büyük örneklemle çocukların sosyal yetkinlik davranışlarını incelemesi ve farklı bir örneklem grubu üzerinde çalışılması bakımından alanyazındaki çalışmalardan farklılaşmaktadır. Bu yönüyle çalışmanın alanyazına katkı sağlayacağı düşünülmektedir.

$\mathrm{Bu}$ araştırmanın amac1, 2017-2018 öğretim yılında MEB'e bağlı okul öncesi eğitim kurumlarına devam eden çocukların sosyal yetkinlik davranışlarını incelemektir. Bu amaç doğrultusunda aşağıdaki sorulara yanıt aranmıştır:

1. Okul öncesi eğitim kurumlarına devam eden çocuklar sosyal yetkinlik davranışlarını ne sıklıkla sergilemektedir?

2. Okul öncesi eğitim kurumlarına eğitime devam eden çocukların sosyal yetkinlik davranışları cinsiyet, yaş, ailenin gelir düzeyi, kardeş sayısı, anne ve baba eğitim düzeyi değişkenlerine göre anlamlı farklılık göstermekte midir?

İnsanın sürekli değişim içinde olan dünyaya her yaşta uyum sağlaması için kazanması gereken becerilerden biri sosyal becerilerdir. Yetenek ve becerilerin farkında olan, özgüveni yüksek, olumlu benlik algısına sahip bireylerin akranlarıyla ve toplumla sağlıklı sosyal ilişkiler kurmaları beklenmektedir. Sosyal yetkinliğin göstergesi olan sosyal becerilere sahip olmak için tüm gelişim alanlarında kritik öneme sahip olan okul öncesi dönemde bireyin bu becerileri kazanması gerekmektedir. Okul öncesi dönemde yeterli sosyal gelişimin gerçekleşmemesi, çocuğun düşük sosyal yetkinliğe sahip olmasına neden olmaktadır (Haktanır, 2011). Bu durum ise hem çocukluk hem de yetişkinlik döneminde iletişim problemleri ve davranış sorunlarının yaşanması ihtimalini artıracaktır. Dolayısıyla, okul öncesi eğitim kurumlarına devam eden çocukların sosyal yetkinlik davranışlarının belirlenip gerekli önlemlerin alınması ve davranış sorunlarının kaynağına inilip çözümlenmesi gerekmektedir. Bu durumda, öğretmen görüşlerine göre çocukların sosyal yetkinlik davranışlarının çeşitli değişkenlere göre incelendiği bu çalışmanın ilgili alanyazına katkı sunacağı düşünülmektedir.

\section{Yöntem}

\section{Araştırmanın Deseni}

$\mathrm{Bu}$ araştırmada, okul öncesi eğitim kurumlarına devam eden çocukların sosyal yetkinlik davranışlarının ortaya çıkarılması amaçlandığı için betimsel tarama modeli kullanılmıştır. Betimsel tarama modellerinde mevcut olgu, kişi veya durumların var olduğu şekliyle belirlenmesi amaçlanmaktadır (Karasar, 2015).

\section{Evren ve Örneklem}

Bu araştırmanın çalışma evrenini, 2017-2018 eğitim-öğretim yılında Van ili İpekyolu, Tuşba ve Edremit merkez ilçelerinde bulunan okul öncesi eğitim kurumlarında eğitim gören çocuklar oluşturmaktadır. Van İl Milli Eğitim Müdürlüğünden alınan verilere göre; İpekyolu ilçesinde 6286, Tuşba ilçesinde 2779, Edremit ilçesinde ise 3118 çocuk olmak üzere Van ilinin belirtilen üç merkez ilçesinde toplam 12.183 çocuk okul öncesi eğitim kurumlarında eğitim görmektedir.

Araştırmada basit seçkisiz örnekleme yöntemi kullanılmıştır. Basit seçkisiz örnekleme yönteminde, her bir örnekleme biriminin örnekleme seçilme şansı eşittir ve seçkisiz olarak örneklem belirlenirken bireyler veya okul, birim vb. listesi oluşturularak rastgele seçim yapılabilir (Büyüköztürk, Çakmak, Akgün, Karadeniz ve Demirel, 2016). Bu araştırmada, çocukların sosyal yetkinlik davranışları üzerinde etkili olabileceği düşüncesiyle belirlenen ilçelerde yer alan okul öncesi kurumları listelenmiş̧ir ve okullar uzman görüşü alınarak alt, orta ve yüksek sosyo-ekonomik geliş̧mişlik düzeyi olmak üzere üç tabakaya ayrılmıştır. Uzmanlardan okulların sosyoekonomik gelişmişlik düzeyine karar verirken okulun bulunduğu çevrenin ekonomik koşulları, sosyo-kültürel özellikleri, eğitim düzeyi gibi ölçütleri temel almaları istenmiştir ve uzmanlar arasında görüş birliğine varılarak tabakalar ayrılmıştır. Her bir tabakadan belirli sayıda okul öncesi kurumu seçkisiz olarak belirlenmiştir. 
Örneklem büyüklüğünün belirlenmesinde, zaman ve olanaklar bakımından mümkün olabildiğince daha geniş ve evreni temsil edebilecek güçte bir örneklem belirlemek önem taşımaktadır (Fraenkel, Wallen ve Hyun, 2012). Bu araştırmada, araştırmanın evrenini olabildiğince yüksek düzeyde temsil edebilmesi açısından araştırmanın amacına uygun olacak şekilde örnekleme alınan çocuk sayısının yüksek tutulması amaçlanmıştır. Dolayısıyla, belirlenen okul öncesi kurumlarında öğrenim görmekte olan üç ilçeden toplam 521 çocuk araştırmanın örneklemini oluşturmuştur. İlçelere göre örneklem alınırken çalışma evrenindeki oranı dikkate alınmıştır. .05 anlamlılık düzeyinde evren sayısının 10.000 olması durumunda örneklem sayısının 370 olması evreni temsil etme bakımından yeterli görülmektedir (Büyüköztürk ve diğ., 2016). Bu durumda, bu çalışmanın örnekleminin evreni temsil edebilecek büyüklükte olduğu söylenebilir. Araştırmanın örneklemini oluşturan okul öncesi eğitim kurumlarına devam eden çocukların cinsiyete, yaşa, öğrenim gördükleri ilçelere ve okulun sosyo-ekonomik gelişmişlik düzeyine göre dağılımı Tablo 1'de verilmiştir.

Tablo 1

Örneklemde Yer Alan Çocukların Cinsiyete, Yaşa, İlçelere ve Okulun Sosyo-Ekonomik Düzeyine Göre Dă̆llımı

\begin{tabular}{llll}
\hline Özellik & Kategori & Sayı $(N)$ & Yüzde $(\%)$ \\
\hline \multirow{2}{*}{ Cinsiyet } & Kız & 260 & 49.9 \\
& Erkek & 261 & 50.1 \\
Yaş & $36-48$ ay arası & 58 & 11 \\
& $49-60$ ay arası & 281 & 54 \\
İlçe & 11 ve üzeri & 182 & 35 \\
& İpekyolu & 298 & 57 \\
Okulun sosyo-ekonomik gelişmişlik & Edremit & 99 & 19 \\
düzeyi & Yüksek & 124 & 24 \\
& Orta & 212 & 41 \\
& Düşük & 150 & 29 \\
& Toplam & 159 & 30 \\
\hline
\end{tabular}

Tablo 1 verilerine göre, örnekleme alınan okul öncesi eğitim kurumlarına devam eden çocukların yaklaşık olarak yarısı (260; \% 49.9) kız, yaklaşık olarak yarısı (261; \%50.1) ise erkektir. Çocukların 298'i (\%57) İpekyolu ilçesinde, 99'u (\%19) Tuşba ilçesinde ve 124'ü (\% 24) ise Edremit ilçesinde öğrenim görmektedir. Örnekleme alınan okullar sosyo-ekonomik gelişmişlik düzeyine göre incelendiğinde, yüksek sosyo-ekonomik gelişmişlik düzeydeki okullardan $212(\% 41)$, orta sosyo-ekonomik gelişmişlik düzeydeki okullardan 150 (\%29) ve düşük sosyo-ekonomik gelişmişlik düzeydeki okullardan ise 159 (\%30) çocuğun örnekleme alındığı görülmektedir.

\section{Veri Toplama Araçları}

Araştırmada, okul öncesi eğitim kurumlarına devam eden çocukların sosyal yetkinlik davranışlarını belirlemek amacıyla Sosyal Yetkinlik ve Davranış Değerlendirme-30 Ölçeği kullanılmıştır. La Freniere ve Dumas (1996) tarafından geliştirilen ve Çorapçı, Aksan, Arslan-Yalçın ve Yağmurlu (2010) tarafından Türkçeye uyarlanan ölçek, çocuğun öğretmeni veya ebeveyni tarafından doldurulmaktadır. 6'lı Likert tipi ölçek, her biri 10 maddeden oluşan sosyal yetkinlik, kızgınlık-saldırganlık ve anksiyete-içedönüklük olmak üzere üç alt boyuttan oluşmaktadır. Üç faktörün açıkladığı toplam varyans \%48.3 olarak hesaplanmıştır. Ölçekte olumsuz puanlanan madde yoktur. Ölçekten alınabilecek en yüksek değer 150 iken en düşük değer ise 30'dur. Sosyal yetkinlik alt boyutu, çocukların akranlarıyla bir aradayken gösterdikleri işbirliği ve anlaşmazlıklara çözüm yolları aramak gibi olumlu özelliklerini ölçer ve "Grup faaliyetlerinde diğer çocuklarla birlikte çalışır, onlarla işbirliği yapar." gibi maddelerden oluşmaktadır. Kızgınlık-Saldırganlık alt boyutu, çocukların yetişkinlere karsı gelme, akran ilişkilerinde saldırgan davranma gibi sorun belirtilerini ölçer ve "Huysuzdur, çabuk kızıp öfkelenir." gibi maddelerden oluşmaktadır. Anksiyete-içe dönüklük alt boyutu ise çocukların üzgün, depresif duygu durumlarını, grup içinde çekingenlik göstermek gibi sorun belirtilerini ölçer ve "Çekingen, ürkektir; yeni ortamlardan ve durumlardan kaçınır." gibi maddelerden oluşmaktadır. Sosyal yetkinlik, kızgınlık-saldırganlık ve anksiyeteiçedönüklük alt boyutları için Cronbach Alpha iç güvenirlik katsayıları sırasıyla .88, .87, ve .84 olarak bulunmuştur. Bu çalışmada ise ölçeğin alt boyutlarının Cronbach Alpha iç güvenirlik katsayıları sırasıyla .90 , .87, .88 olarak hesaplanmıştır. Bu değerler, ölçekten elde edilen verilerin güvenilir olduğunu göstermektedir. 


\section{Veri Toplama Süreci}

Veri toplama sürecinde, her bir tabakadan belirli sayıda olmak üzere toplam 25 okul öncesi kurumu (bağımsız anaokulları ve ilkokul bünyesindeki anasınıfları) seçkisiz olarak belirlenmiştir. Okullarda ikili eğitim yapıldığı için bazı öğretmenlerle doğrudan görüşülerek, bazı öğretmenlere ise yöneticileriyle görüşülerek ölçek uygulamasına ilişkin genel bilgi ve yönergeler açıklanmıştır. Her öğretmenden sınıf listesinden dört kız, dört erkek olmak üzere seçkisiz olarak sekiz çocuk seçmesi ve öğretmenden her çocuğa ilişkin sosyal yetkinlik ölçeğini doldurmaları istenmiştir. Toplamda 190 öğretmenle iletişime geçilmiş ve 144 öğretmenden dönüt alınmıştır. Bu durumda, her bir öğretmenden yaklaşık olarak üç-dört öğrencisiyle ilgili veri toplanmıştır. Veri toplama süreci yaklaşık olarak sekiz hafta sürmüştür.

\section{Veri Analizi}

Araştırmada okul öncesi eğitim kurumlarına devam eden çocukların sosyal yetkinlik davranışlarını belirlemek için ölçek puanlarına ilişkin aritmetik ortalama ve standart sapma değerleri incelenmiştir. Bu değerler '1-1.99 arası' neredeyse hiç, '2.00-2.99 arası' nadiren, '3.00-3.99 arası' bazen, '4.00-4.99 aras1' slkllkla ve '5.00-6.00 arası' her zaman olarak yorumlanmıștır. Çocukların sosyal yetkinlik davranışlarının cinsiyet, yaş, kardeş sayısı, annebaba eğitim düzeyi, ailenin gelir düzeyi değişkenlerine göre anlamlı farklılık gösterip göstermediğine ilişkin çok değişkenli varyans analizi (MANOVA) kullanılmıştır. MANOVA sonuçları anlamlı çıkması durumunda tek yönlü varyans analizi (ANOVA) yapılabilir (Field, 2009, Akt. Aypay, Çekiç ve Seçkin, 2012). Bu durumda, MANOVA testi sonuçlarında anlamlı fark çıkması üzerine belirlenen değişkenlere göre grup ortalamalarının nasıl farklılık gösterdiğini ortaya koymak amacıyla ANOVA testi uygulanmıştır. Analizlerde anlamlılık düzeyi .05 olarak belirlenmiş̧tir. MANOVA testinin .05 düzeyinde anlamlı çıkması durumunda yapılan ANOVA testlerinde I.tip hatayı önlemek için Bonferroni düzeltmesi (correction) yapılmıştır. Bonferroni düzeltmesinde, anlamlılık düzeyi bağımlı değişken sayısına bölünmektedir (Miller, 1991). Bu durumda, anlamlılık düzeyi Bonferroni düzeltmesi ile sosyal yetkinlik davranışları ölçeğinin alt boyutları için .017 (.05/3) olarak belirlenmiştir (Büyüköztürk, 2013; Cohen, 1988). Ayrıca, ANOVA testinde yapılan karşılaştırma sonucunda anlamlı fark çıkması durumunda, farkın kaynağını belirlemek için çoklu karşılaştırma testlerinden Scheffe testi kullanılmıştır.

Analizler öncesinde, MANOVA testinin yapılabilmesi için gerekli olan varsayımlar ele alınmıştır. Bu doğrultuda, araştırma verilerine iliş̧in doğrusallık, tek ve çok değişkenli normallik, varyans-kovaryans matrisinin homojenliği ve çoklu bağlantı problemi olup olmadığı incelenmiştir (Büyüköztürk, 2013; Pallant, 2005). Tek değişkenli normallik için bağımlı değişkenlere ait histogram grafikleri incelenmiş, ayrıca çarpıklık ve basıklık değerlerine bakılmıştır. Bunun sonucunda, sosyal yetkinlik davranışları ölçeğinde bağımlı değişkenlere ait puanların çarpıklık (skewness) değerlerinin - 0.515 ile 0.780 arasında değiştiği, basıklık (kurtosis) değerlerinin ise -0.482 ile 0.951 arasında değiştiği belirlenmiştir. Bu durumda, bağımlı değişkenlere ait puanlara ilişkin çarpıklık ve basıklık katsayılarının \pm 1 aralığında olduğu dikkate alınarak ve histogram grafiklerine bakılarak verilerin normal dağılım gösterdiği kabul edilmiştir (Büyüköztürk, 2013). Varyansların homojenliği için Levene's Test ve Kovaryans matrislerinin dağılımı için ise Box's M sonuçları incelenmiştir. Yapılan analizler sonucunda, bu sonuçların istatistiksel olarak anlamlı olmadığı $(p>.05)$ ve dolayısıyla varyans- kovaryans matrislerinin homojenliği varsayımlarının karşılandığı sonucuna ulaşılmışı̧ı (Büyüköztürk, 2013). Çok değişkenli normallik için Mahalonobis uzaklık değerleri hesaplanmış ve uç değerler analiz öncesinde veri setinden çıkarılmıştır. Bağımlı değişkenler arasındaki doğrusallık saçılım grafikleri ile incelenmiş ve ölçeklerin alt boyutlarına ilişkin doğrusallık varsayımının karşılandığı belirlenmiştir. Bu sonuçlardan hareketle, çok değişkenli normallik ve doğrusallığın sağlandığı, bağımlı değişkenler arasında çoklu bağlantı problemi olmadığı sonucuna ulaşılmıştır.

\section{Bulgular}

\section{Birinci Alt Probleme İlişkin Bulgular}

Araştırmanın birinci alt problemi olan "Okul öncesi eğitim kurumlarına devam eden çocuklar sosyal yetkinlik davranışlarını ne sıklıkla sergilemektedir?" sorusuna yönelik olarak çocukların öğretmenlerinin ölçek maddelerine verdikleri yanıtlar üzerinden hesaplanan aritmetik ortalama ve standart sapma değerleri Tablo 2'de sunulmuştur. 
Tablo 2

Okul Öncesi Eğitim Kurumlarına Devam Eden Çocukların Sosyal Yetkinlik Davranışlarına İlişkin Ortalama ve Standart Sapma Değerleri

\begin{tabular}{lcc}
\hline Ölçek Alt Boyutları & $\bar{X}$ & $s s$ \\
\hline Sosyal yetkinlik & 4.44 & 1.01 \\
Kızgınlık-saldırganlık & 1.97 & 0.77 \\
Anksiyete- içedönüklük & 1.95 & 0.82 \\
\hline
\end{tabular}

Tablo 2 incelendiğinde, okul öncesi eğitim kurumlarına devam eden çocukların sosyal yetkinlik davranışlarını sıklıkla $(\bar{X}=4.44)$ sergiledikleri belirlenirken, kızgınlık-saldırganlık $(\bar{X}=1.97)$ ve anksiyete-içedönüklük $(\bar{X}=1.95)$ davranışlarını neredeyse hiç sergilemedikleri görülmektedir.

\section{İkinci Alt Probleme İlişskin Bulgular}

Araştırmanın ikinci alt problemi olan “Okul öncesi eğitim kurumlarına devam eden çocukların sosyal yetkinlik davranışları cinsiyet, yaş, ailenin gelir düzeyi, kardeş sayısı, anne ve baba eğitim düzeyi değişkenlerine göre anlamlı farklılık göstermekte midir?" sorusuna yönelik olarak yapılan analizlerden elde edilen bulgular aşağıda sırasıyla sunulmuştur.

Çocukların sosyal yetkinlik davranışları ölçeğinin alt boyutlarına ilişkin puanlarının cinsiyete göre anlamlı düzeyde farklılaşıp farklılaşmadığının belirlenmesi için MANOVA testi yapıllmış ve sonuçlar Tablo 3'te sunulmuştur.

Tablo 3

Okul Öncesi Ĕ̆itim Kurumlarına Devam Eden Çocukların Sosyal Yetkinlik Davranışlarının Cinsiyete Göre MANOVA Sonuçları

\begin{tabular}{lllll}
\hline Wilks' Lambda & F & Hipotez sd & Hata sd & $p$ \\
\hline .939 & 11.273 & 3 & 517 & .000 \\
\hline
\end{tabular}

Tablo 3'te görüldüğü üzere, okul öncesi eğitim kurumlarına devam eden çocukların sosyal yetkinlik ölçeğinin alt boyutlarından aldıkları puanlarda .05 anlamlılık düzeyinde cinsiyete göre anlamlı fark bulunmuştur (Wilks' Lambda $.939, F(3,517)=11.273, p<.05)$. MANOVA testinde anlamlı fark çıkması nedeniyle, cinsiyete göre grup ortalamalarının nasıl farklılaştı̆̆ını inceleyebilmek amacıyla ANOVA testi yapılmış ve sonuçlar Tablo 4'te sunulmuştur.

Tablo 4

Okul Öncesi Eğitim Kurumlarına Devam Eden Çocukların Sosyal Yetkinlik Davranışlarının Cinsiyete Göre ANOVA Sonuçları

\begin{tabular}{|c|c|c|c|c|c|c|c|c|c|c|}
\hline \multicolumn{5}{|c|}{ Betimsel İstatistikler } & \multicolumn{6}{|c|}{ ANOVA Sonuçları } \\
\hline Alt Boyutlar & Cinsiyet & $N$ & $\bar{X}$ & ss & $\begin{array}{l}\text { Varyans } \\
\text { Kaynăgl }\end{array}$ & $K . T$ & $s d$ & K.O & $F$ & $p$ \\
\hline $\begin{array}{l}\text { Sosyal } \\
\text { yetkinlik }\end{array}$ & $\begin{array}{l}\text { K1z } \\
\text { Erkek }\end{array}$ & $\begin{array}{l}260 \\
261\end{array}$ & $\begin{array}{l}4.60 \\
4.27\end{array}$ & $\begin{array}{l}0.96 \\
1.04\end{array}$ & $\begin{array}{l}\text { Gruplar arası } \\
\text { Gruplar içi } \\
\text { Toplam }\end{array}$ & $\begin{array}{l}14.809 \\
520.419 \\
535.227\end{array}$ & $\begin{array}{l}1 \\
519 \\
520\end{array}$ & $\begin{array}{l}14.809 \\
1.003\end{array}$ & 14.768 & .000 \\
\hline $\begin{array}{l}\text { Kızgınlık- } \\
\text { saldırganlık }\end{array}$ & $\begin{array}{l}\text { Kiz } \\
\text { Erkek }\end{array}$ & $\begin{array}{l}260 \\
261\end{array}$ & $\begin{array}{l}1.87 \\
2.07\end{array}$ & $\begin{array}{l}0.73 \\
0.80\end{array}$ & $\begin{array}{l}\text { Gruplar arası } \\
\text { Gruplar içi } \\
\text { Toplam }\end{array}$ & $\begin{array}{l}4.842 \\
306.480 \\
311.322\end{array}$ & $\begin{array}{l}1 \\
519 \\
520\end{array}$ & $\begin{array}{l}4.842 \\
0.591\end{array}$ & 8.200 & .004 \\
\hline $\begin{array}{l}\text { Anksiyete - } \\
\text { içe dönüklük }\end{array}$ & $\begin{array}{l}\text { Kiz } \\
\text { Erkek }\end{array}$ & $\begin{array}{l}260 \\
261\end{array}$ & $\begin{array}{l}1.99 \\
1.95\end{array}$ & $\begin{array}{l}0.89 \\
0.75\end{array}$ & $\begin{array}{l}\text { Gruplar arası } \\
\text { Gruplar içi } \\
\text { Toplam }\end{array}$ & $\begin{array}{l}0.976 \\
350.966 \\
351.942\end{array}$ & $\begin{array}{l}1 \\
519 \\
520\end{array}$ & $\begin{array}{l}0.976 \\
0.676\end{array}$ & 1.443 & .230 \\
\hline
\end{tabular}

Tablo 4 incelendiğinde, kız çocukların erkek çocuklara kıyasla sosyal yetkinlik ve anksiyete-içe dönüklük alt boyutlarında daha yüksek ortalamaya, kızgınlık-saldırganlık alt boyutunda ise daha düşük ortalamaya sahip oldukları anlaşılmaktadır. Buna göre, okul öncesi eğitim kurumlarına kurumuna devam eden çocukların sosyal yetkinlik davranışlarında cinsiyet değişkenine göre sosyal yetkinlik alt boyutunda kız çocukların lehine, kızgınlık-saldırganlık alt boyutunda ise erkek çocukların lehine anlamlı fark olduğu belirlenmiştir $(p<.017)$. 
Anksiyete-içedönüklük alt boyutunda ise çocukların anksiyete-içedönüklük davranışlarının cinsiyet değişkenine göre anlamlı farklılık göstermediği belirlenmiştir $(p>.017)$

Okul öncesi eğitim kurumlarına devam eden çocukların sosyal yetkinlik davranışlarının yaşa ve ailenin gelir düzeyine göre anlamlı düzeyde farklılaşıp farklılaşmadı̆̆ını belirlemek amacıyla yapılan MANOVA testi sonuçları Tablo 5 'te sunulmuştur.

Tablo 5

Okul Öncesi Eğitim Kurumlarına Devam Eden Çocukların Oyun Davranışlarının Yaşa ve Ailenin Gelir Düzeyine Göre MANOVA Sonuçlarl

\begin{tabular}{llllll}
\hline Bağımsız Dĕ̆işken & Wilks' Lambda & $F$ & Hipotez sd & Hata sd & $p$ \\
\hline Yaş & .992 & 0.727 & 6 & 1032 & .628 \\
Aile Gelir Düzeyi & .973 & 1.551 & 9 & 1253 & .125 \\
\hline
\end{tabular}

Bu araştırmadaki çocukların 58'i 4 yaş aralığında, 282'si 5 yaş aralığında, 181'i ise 6 yaş aralığındadır. Ayrıca, çocukların 181'inin aile gelir düzeyi 0-1499 TL aralığında, 149'unun aile gelir düzeyi 1.500-2499 TL aralığında, 82 'sinin aile gelir düzeyi 2.500-3499 TL aralığında, 109'unun aile gelir düzeyi ise 3.500 TL ve üzeridir. Tablo 5 'te görüldüğü üzere, okul öncesi eğitim kurumlarına devam eden çocukların sosyal yetkinlik davranışları ölçeğinin alt boyutlarından aldıkları puanlarda .05 anlamlılık düzeyinde yaşa (Wilks’ Lambda .992, $F(6,1032)$ $=0.727, p>.05)$ ve aile gelir düzeyine (Wilks' Lambda .973, $F(9,1253)=1.551, p>.05)$ göre anlaml fark bulunmamıştır. Bu durumda, okul öncesi eğitim kurumlarına devam eden çocukların sosyal yetkinlik davranışlarının yaşa ve aile gelir düzeyine göre anlamlı düzeyde farklılaşmadı̆̆ı görülmektedir.

Çocukların sosyal yetkinlik ölçeğinin alt boyutlarına ilişkin puanlarının kardeş sayısına göre anlamlı düzeyde farklılaşıp farklılaşmadığını belirlenmesi için MANOVA testi yapılmış ve sonuçlar Tablo 6'da sunulmuştur.

Tablo 6

Okul Öncesi Eğitim Kurumlarına Devam Eden Çocukların Sosyal Yetkinlik Davranışlarının Kardeş Sayısına Göre MANOVA Sonuçları

\begin{tabular}{lllll}
\hline Wilks' Lambda & $F$ & Hipotez sd & Hata sd & $p$ \\
\hline .967 & 1.915 & 9 & 1253 & .046 \\
\hline
\end{tabular}

Tablo 6'da görüldüğü üzere, okul öncesi eğitim kurumlarına devam eden çocukların sosyal yetkinlik ölçeğinin alt boyutlarından aldıkları puanlarda .05 anlamlılık düzeyinde kardeş sayısına göre anlamlı fark bulunmuştur (Wilks' Lambda .967, $F(9,1253)=1.915, p<.05)$. MANOVA testinde anlamlı fark çıkması nedeniyle, kardeş sayısına göre grup ortalamalarının nasıl farklılaştığını inceleyebilmek amacıyla ANOVA testi yapılmış ve sonuçlar Tablo 7'de sunulmuştur.

Tablo 7

Okul Öncesi Eğitim Kurumlarına Devam Eden Çocukların Sosyal Yetkinlik Davranışlarının Kardeş Sayısına Göre ANOVA Sonuçları

\begin{tabular}{|c|c|c|c|c|c|c|c|c|c|c|c|}
\hline \multicolumn{5}{|l|}{ Betimsel İstatistikler } & \multicolumn{7}{|c|}{ ANOVA Sonuçları } \\
\hline Alt Boyutlar & Kardeş Sayısı & $N$ & $\bar{X}$ & ss & $\begin{array}{l}\text { Varyans } \\
\text { Kaynağı }\end{array}$ & $K . T$ & $s d$ & K.O & $F$ & $p$ & 胥 \\
\hline \multirow{4}{*}{ Sosyal yetkinlik } & Kardeş yok & 55 & 4.46 & 0.93 & Gruplar aras1 & 7.594 & 3 & 2.531 & \multirow[t]{4}{*}{2.48} & \multirow[t]{4}{*}{.060} & \\
\hline & 1 & 237 & 4.54 & 1.01 & Gruplar içi & 527.633 & 517 & 1.021 & & & \\
\hline & 2 & 133 & 4.41 & 1.09 & Toplam & 535.227 & 520 & & & & \\
\hline & 3 ve üzeri & 96 & 4.21 & 0.95 & & & & & & & \\
\hline \multirow{4}{*}{ Kızgınlık-saldırganlık } & Kardeş yok & 55 & 1.95 & 0.75 & Gruplar aras1 & 4.120 & 3 & 1.373 & \multirow[t]{4}{*}{2.31} & \multirow[t]{4}{*}{.075} & \\
\hline & 1 & 237 & 1.89 & 0.70 & Gruplar içi & 307.202 & 517 & 0.594 & & & \\
\hline & 2 & 133 & 2.00 & 0.84 & Toplam & 311.322 & 520 & & & & \\
\hline & 3 ve üzeri & 96 & 2.13 & 0.84 & & & & & & & \\
\hline \multirow{4}{*}{ Anksiyete-içe dönüklük } & Kardeş yok & 55 & 1.73 & 0.58 & Gruplar aras1 & 8.040 & 3 & 2.680 & \multirow[t]{4}{*}{4.02} & \multirow[t]{4}{*}{.008} & $4>1$ \\
\hline & 1 & 237 & 1.89 & 0.82 & Gruplar içi & 343.903 & 517 & 0.665 & & & $4>2$ \\
\hline & 2 & 133 & 2.00 & 0.86 & Toplam & 351.942 & 520 & & & & \\
\hline & 3 ve üzeri & 96 & 2.16 & 0.86 & & & & & & & \\
\hline
\end{tabular}

1) Kardeş yok. 2) 1 kardeş, 3) 2 kardeş, 4) 3 ve üzeri kardeş 
Tablo 7 incelendiğinde, okul öncesi eğitim kurumlarına devam eden çocukların sosyal yetkinlik ve kızgınlıksaldırganlık davranışları kardeş sayısına göre anlamlı farklılık göstermezken sosyal yetkinlik ölçeğinin sadece anksiyete-içedönüklük alt boyutunda kardeş sayısına göre ortaya çıkan farkın anlamlı düzeyde olduğu görülmektedir $(p<$.017). Çocukların kardeş sayısına göre farklılaşan ortalamalarının hangi gruplardan kaynaklandığını belirlemek amacıyla yapılan çoklu karşılaştırma testlerinden Scheffe testi sonucunda; üç ve üzeri kardeşi olan çocuklar ile kardeşi olmayan ve bir kardeşi olan çocuklar arasında anksiyete-içedönüklük davranışlarının üç ve üzeri kardeş olan çocukların lehine anlamlı farklılık gösterdiği ortaya çıkmıştır. Bir başka deyişle, üç ve üzeri kardeş olan çocukların anksiyete-içe dönüklük davranışlarını daha çok sergiledikleri belirlenmiştir.

Çocukların sosyal yetkinlik ölçeğinin alt boyutlarına ilişkin puanlarının anne eğitim düzeyine göre anlamlı düzeyde farklılaşıp farklılaşmadığını belirlenmesi için MANOVA testi yapılmış ve sonuçlar Tablo 8'de sunulmuştur.

Tablo 8

Okul Öncesi Eğitim Kurumlarına Devam Eden Çocukların Sosyal Yetkinlik Davranışlarının Anne Eğitim Düzeyine Göre MANOVA Sonuçları

\begin{tabular}{lllll}
\hline Wilks' Lambda & $F$ & Hipotez sd & Hata sd & $p$ \\
\hline .933 & 2.993 & 12 & 1360 & .000 \\
\hline
\end{tabular}

Tablo 8'de görüldüğü üzere, okul öncesi eğitim kurumlarına devam eden çocukların sosyal yetkinlik ölçeğinin alt boyutlarından aldıkları puanlarda .05 anlamlılık düzeyinde anne eğitim düzeyine göre anlamlı fark bulunmuştur (Wilks' Lambda .933, $F(9,1360)=2.993, p<.05)$. MANOVA testinde anlamlı fark çıkmas1 nedeniyle, anne eğitim düzeyine göre grup ortalamalarının nasıl farklılaştığını inceleyebilmek amacıyla ANOVA testi yapılmış ve sonuçlar Tablo 9'da sunulmuştur.

Tablo 9

Okul Öncesi Eğitim Kurumlarına Devam Eden Çocukların Sosyal Yetkinlik Davranışlarının Anne Eğitim Düzeyine Göre ANOVA Sonuçları

\begin{tabular}{|c|c|c|c|c|c|c|c|c|c|c|c|}
\hline \multicolumn{5}{|c|}{ Betimsel İstatistikler } & \multicolumn{7}{|c|}{ ANOVA Sonuçları } \\
\hline Alt Boyutlar & $\begin{array}{l}\text { Anne Ĕ̆itim } \\
\text { Düzeyi }\end{array}$ & $N$ & $\bar{X}$ & ss & $\begin{array}{l}\text { Varyans } \\
\text { Kaynağ } l\end{array}$ & $K . T$ & $s d$ & K.O & $F$ & $p$ & 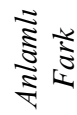 \\
\hline \multirow{6}{*}{ Sosyal yetkinlik } & Okur-yazar & 78 & 4.15 & 1.06 & Gr.Aras1 & 18.341 & 4 & 4.585 & \multirow[t]{6}{*}{4.578} & \multirow[t]{6}{*}{.001} & $5>1$ \\
\hline & değil & 159 & 4.35 & 1.03 & Gr. İçi & 516.886 & 516 & 1.002 & & & $5>2$ \\
\hline & İlkokul & 96 & 4.41 & 1.01 & Toplam & 535.227 & 520 & & & & \\
\hline & Ortaokul & 107 & 4.55 & 0.95 & & & & & & & \\
\hline & Lise & 81 & 4.77 & 0.94 & & & & & & & \\
\hline & Üniversite & & & & & & & & & & \\
\hline \multirow{6}{*}{$\begin{array}{l}\text { Kızgınlık- } \\
\text { saldırganlık }\end{array}$} & Okur-yazar & 78 & 2.21 & 0.97 & Gr.Aras1 & 11.951 & 4 & 2.988 & \multirow[t]{6}{*}{5.150} & \multirow[t]{6}{*}{.000} & $1>5$ \\
\hline & değil & 159 & 2.03 & 0.76 & Gr. içi & 299.371 & 516 & 0.580 & & & $1>4$ \\
\hline & İlkokul & 96 & 2.04 & 0.74 & Toplam & 311.322 & 520 & & & & \\
\hline & Ortaokul & 107 & 1.81 & 0.64 & & & & & & & \\
\hline & Lise & 81 & 1.75 & 0.69 & & & & & & & \\
\hline & Üniversite & & & & & & & & & & \\
\hline \multirow{6}{*}{$\begin{array}{l}\text { Anksiyete-içe } \\
\text { dönüklük }\end{array}$} & Okur-yazar & 78 & 2.08 & 0.83 & Gr.Aras1 & 12.167 & 4 & 3.042 & \multirow[t]{6}{*}{4.619} & \multirow[t]{6}{*}{.001} & \multirow[t]{6}{*}{$1>4$} \\
\hline & değil & 159 & 2.08 & 0.88 & Gr. içi & 339.775 & 516 & 0.658 & & & \\
\hline & İlkokul & 96 & 2.01 & 0.81 & Toplam & 351.942 & 520 & & & & \\
\hline & Ortaokul & 107 & 1.73 & 0.68 & & & & & & & \\
\hline & Lise & 81 & 1.78 & 0.82 & & & & & & & \\
\hline & Üniversite & & & & & & & & & & \\
\hline
\end{tabular}

1) Okur-yazar değil, 2) İlkokul, 3) Ortaokul, 4) Lise, 5) Üniversite

Tablo 9 incelendiğinde, okul öncesi eğitim kurumlarına devam eden çocukların sosyal yetkinlik davranışlarının anne eğitim düzeyine göre farklılaştığı anlaşılmaktadır. Tablo 9 verilerine göre, sosyal yetkinlik ölçeğinin tüm alt boyutlarında anne eğitim düzeyine göre ortaya çıkan farkın anlamlı düzeyde olduğu görülmektedir $(p<.017)$. Anne eğitim düzeyine göre farklılaşan ortalamaların hangi gruplardan kaynaklandığını belirlemek amacıyla yapılan çoklu karşılaştırma testlerinden Scheffe testi sonucunda; sosyal yetkinlik alt boyutunda annesi üniversite 
mezunu olan çocuklar ile annesi okuryazar olmayan ve ilkokul mezunu olan çocuklar arasında annesi üniversite mezunu olan çocuklar lehine anlamlı farklılık olduğu belirlenmiştir. Bir başka deyişle, annesi üniversite mezunu olan çocukların sosyal yetkinlik davranışlarını daha çok sergiledikleri belirlenmiştir. Ayrıca, kızgınlıksaldırganlık alt boyutunda annesi okur-yazar olmayan çocuklar ile annesi lise ve üniversite mezunu olan çocuklar arasında annesi okur-yazar olmayan çocuklar lehine anlamlı farklılık olduğu, anksiyete-içedönüklük alt boyutunda ise annesi okur-yazar olmayan çocuklar ile annesi lise mezunu olan çocuklar arasında annesi okuryazar olmayan çocuklar lehine anlamlı farklılık olduğu ortaya çıkmıştır. Bir başka deyişle, annesi okur-yazar olmayan çocukların kızgınlık-saldırganlık ve anksiyete-içe dönüklük davranışlarını daha çok sergiledikleri belirlenmiştir.

Çocukların sosyal yetkinlik ölçeğinin alt boyutlarına ilişkin puanlarının baba eğitim düzeyine göre anlamlı düzeyde farklılaşıp farklılaşmadığını belirlenmesi için MANOVA testi yapılmış ve sonuçlar Tablo 10'da sunulmuştur.

Tablo 10

Okul Öncesi Eğitim Kurumlarına Devam Eden Çocukların Sosyal Yetkinlik Davranışlarının Baba Eğitim Düzeyine Göre MANOVA Sonuçlart

\begin{tabular}{lllll}
\hline Wilks' Lambda & $F$ & Hipotez sd & Hata sd & $p$ \\
\hline .966 & 1.968 & 9 & 1253 & .040 \\
\hline
\end{tabular}

Tablo 10’da görüldüğü üzere, okul öncesi eğitim kurumlarına devam eden çocukların sosyal yetkinlik ölçeğinin alt boyutlarından aldıkları puanlarda .05 anlamlılık düzeyinde baba eğitim düzeyine göre anlamlı fark bulunmuştur (Wilks' Lambda .933, $F(9,1253)=1.968, p<.05)$. MANOVA testinde anlamlı fark çıkmas1 nedeniyle, baba eğitim düzeyine göre grup ortalamalarının nasıl farklılaştığını inceleyebilmek amacıyla ANOVA testi yapılmış ve sonuçlar Tablo 11 'de sunulmuştur.

Tablo 11

Okul Öncesi Eğitim Kurumlarına Devam Eden Çocukların Sosyal Yetkinlik Davranışlarının Baba Eğitim Düzeyine Göre ANOVA Sonuçları

\begin{tabular}{|c|c|c|c|c|c|c|c|c|c|c|c|}
\hline \multicolumn{5}{|c|}{ Betimsel İstatistikler } & \multicolumn{7}{|c|}{ ANOVA Sonuçları } \\
\hline Alt Boyutlar & $\begin{array}{l}\text { Baba } \\
\text { Eğitim } \\
\text { Düzeyi }\end{array}$ & $N$ & $\bar{X}$ & ss & $\begin{array}{l}\text { Varyans } \\
\text { Kaynă̆g }\end{array}$ & $K . T$ & $s d$ & K.O & $F$ & $p$ & 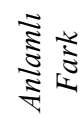 \\
\hline $\begin{array}{l}\text { Sosyal } \\
\text { yetkinlik }\end{array}$ & $\begin{array}{l}\text { İlkokul } \\
\text { Ortaokul } \\
\text { Lise } \\
\text { Üniversite }\end{array}$ & $\begin{array}{l}126 \\
92 \\
162 \\
141\end{array}$ & $\begin{array}{l}4.21 \\
4.35 \\
4.49 \\
4.63\end{array}$ & $\begin{array}{l}1.06 \\
1.01 \\
0.96 \\
1.01\end{array}$ & $\begin{array}{l}\text { Gruplar arası } \\
\text { Gruplar içi } \\
\text { Toplam }\end{array}$ & $\begin{array}{l}12.534 \\
522.693 \\
535.227\end{array}$ & $\begin{array}{l}3 \\
517 \\
520\end{array}$ & $\begin{array}{l}4.178 \\
1.011\end{array}$ & 4.133 & .007 & $4>1$ \\
\hline $\begin{array}{l}\text { Kızgınlık } \\
\text { saldırganlık }\end{array}$ & $\begin{array}{l}\text { İlkokul } \\
\text { Ortaokul } \\
\text { Lise } \\
\text { Üniversite }\end{array}$ & $\begin{array}{l}126 \\
92 \\
162 \\
141\end{array}$ & $\begin{array}{l}2.10 \\
2.06 \\
1.90 \\
1.87\end{array}$ & $\begin{array}{l}0.78 \\
0.79 \\
0.77 \\
0.75\end{array}$ & $\begin{array}{l}\text { Gruplar arası } \\
\text { Gruplar içi } \\
\text { Toplam }\end{array}$ & $\begin{array}{l}5.018 \\
306.304 \\
311,322\end{array}$ & $\begin{array}{l}3 \\
517 \\
520\end{array}$ & $\begin{array}{l}1.673 \\
0.592\end{array}$ & 2.823 & .038 & \\
\hline $\begin{array}{l}\text { Anksiyete- } \\
\text { içedönüklük }\end{array}$ & $\begin{array}{l}\text { İlkokul } \\
\text { Ortaokul } \\
\text { Lise } \\
\text { Üniversite }\end{array}$ & $\begin{array}{l}126 \\
92 \\
162 \\
141\end{array}$ & $\begin{array}{l}2.04 \\
2.08 \\
1.93 \\
1.80\end{array}$ & $\begin{array}{l}0.83 \\
0.76 \\
0.83 \\
0.82\end{array}$ & $\begin{array}{l}\text { Gruplar arası } \\
\text { Gruplar içi } \\
\text { Toplam }\end{array}$ & $\begin{array}{l}5.831 \\
346.112 \\
351.942\end{array}$ & $\begin{array}{l}3 \\
517 \\
520\end{array}$ & $\begin{array}{l}1.944 \\
0.669\end{array}$ & 2.903 & .034 & \\
\hline
\end{tabular}

1) İlkokul, 2) Ortaokul, 3) Lise, 4) Üniversite

Tablo 11 incelendiğinde, okul öncesi eğitim kurumlarına devam eden çocukların sosyal yetkinlik davranışlarının baba eğitim düzeyine göre farklılaştığı anlaşılmaktadır. Tablo 11 verilerine göre, sosyal yetkinlik ölçeğinin sadece sosyal yetkinlik alt boyutunda baba eğitim düzeyine göre ortaya çıkan farkın anlamlı düzeyde olduğu görülmektedir $(p<.017)$. Baba eğitim düzeyine göre farklılaşan ortalamaların hangi gruplardan kaynaklandığını belirlemek amacıyla yapılan çoklu karşılaştırma testlerinden Scheffe testi sonucunda; sosyal yetkinlik alt boyutunda babası üniversite mezunu olan çocuklar ile babası ilkokul mezunu olan çocuklar arasında babası üniversite mezunu olan çocuklar lehine anlamlı farklılık olduğu belirlenmiştir. Bir başka deyişle, babası üniversite mezunu olan çocukların sosyal yetkinlik davranışlarını daha çok sergiledikleri belirlenmiştir. 


\section{Sonuç ve Tartışma}

Araştırmada, okul öncesi eğitim kurumlarına devam eden çocukların sosyal yetkinlik davranışlarını sıklıkla sergiledikleri, anksiyete-içedönüklük ve kızgınlık-saldırganlık davranışlarını ise neredeyse hiç sergilemedikleri sonucuna ulaşılmışır. Bu çalışma sonuçları, alanyazındaki benzer çalışma sonuçlarıyla paralellik göstermektedir. Alanyazında okul öncesi eğitim kurumlarına devam eden çocuklarla yürütülen birçok çalışmada (Çorapçı ve diğ., 2010; Gür ve diğ., 2015; Keçecioğlu, 2015; Özkan ve Tozduman Yaral1, 2016; Ural, Güven, Sezer, Azkeskin ve Yılmaz, 2015) çocukların sosyal yetkinlik davranışlarını daha çok sergiledikleri sonucuna ulaşılmıştır. Bu durumda, okul öncesi eğitimi alan çocukların içedönüklük ve saldırganlık davranışlarından ziyade sosyal yetkinlik davranışlarını daha çok sergiledikleri görülmektedir. Okul öncesi dönemin sosyal becerilerin gelişiminde kritik öneme sahip olduğu düşünüldüğünde, bu araştırma sonuçları olumlu olarak değerlendirilebilir. Alanyazında sosyal yetkinliğe sahip çocukların çocuğun kendini ve duygularını tanıdığı, kontrol edebildiği, çevresiyle sağlıklı iletişim kurabildiği, olumlu benlik algısına sahip olduğu ifade edilmektedir (Çorapçı ve diğ., 2010; Çorbacı, 2008; Haktanır, 2011). Bu araştırma sonuçları değerlendirildiğinde, okul öncesi eğitim kurumlarına devam eden çocukların kendini ve duygularını ifade edebildikleri, akranlarıyla sağlıklı iletişim kurabildikleri, kısacası okul öncesi dönemde kazanması gereken sosyal becerilere sahip oldukları söylenebilir.

Araştırmada, okul öncesi eğitim kurumlarına devam eden çocukların sosyal yetkinlik puanlarının cinsiyete göre anlamlı düzeyde farklılaş̧ı̆̆ı, kız çocuklarının sosyal yetkinlik puanlarının erkek çocuklarından daha yüksek olduğu sonucuna ulaşılmıştır. Öte yandan, kizglnlık-saldırganlık alt boyutunda cinsiyete göre anlamlı farklılık olduğu, erkek çocukların kız çocuklarına kıyasla kızgınlık-saldırganlık davranışlarını daha çok sergiledikleri belirlenmiş̧ir. Alanyazında bu çalışma sonuçlarıyla benzer ve farklı sonuçlara ulaşan çalışmalar bulunmaktadır. $\mathrm{Bu}$ araştırma sonuçlarına paralel olarak, alanyazında kız çocuklarının sosyal yetkinlik puanlarının erkek çocuklardan daha yüksek olduğu, erkek çocukların ise saldırganlık puanlarının kız çocuklarından daha yüksek olduğu sonucuna ulaşan birçok çalı̧̧ma (Altay ve Güre, 2012; And1, 2014; Aunola ve Nurmi, 2005; Chen ve Jiang, 2002; Cohn, 1990; Çorapçı ve diğ., 2010; Gülay, 2008; Gür ve diğ., 2015; Karaca ve diğ., 2011; Kanlıkılınçer, 2005; Keçecioğlu 2015; Ogelman ve Topaloğlu, 2014; Özbey ve Alisinanoğlu, 2009; Rydel, Bohlin ve Thorell, 2005; Sezici, 2013; Ural ve diğ., 2015) bulunmaktadır. Benzer şekilde, Hammarberg ve Hagekull (2006) yaptıkları çalışmada, erkek çocukların dışsallaştırma ve içselleştirme davranış puanlarının kız çocuklarına göre daha yüksek olduğunu belirlemişlerdir. Bu çalışma sonuçlarından farklı olarak, Nalbant (2016) yaptığı çalışmada, kız ve erkek çocukların sosyal yetkinlik toplam puanında cinsiyete göre anlamlı bir farklılık olmadığı sonucuna ulaşmıştır. Şendil (2010) yaptığ çalışmada, çocukların sosyal yetkinlik, anksiyete ve saldırganlık davranışlarında cinsiyete göre anlamlı bir farklılık olmadığını belirlemiştir. Alanyazındaki araştırma sonuçları incelendiğinde, çocukların sosyal yetkinlik davranışları ve sosyal becerilerinin cinsiyete göre farklılaşıp farklılaşmadığının araştırıldığı görülmektedir. Çoğu araştırmada çocukların sosyal yetkinlik ve kızgınlık-saldırganlık puanlarının cinsiyete göre anlamlı düzeyde farklılaştığı, bazı araştırmalarda ise anlamlı farklılaşmanın olmadığı sonucuna ulaşılmıştır. Kız çocuklarının dil gelişiminin erkek çocuklara göre daha erken başlaması ve hızlı olması (Denham ve diğ., 2003) kız çocuklarının daha kolay kendini ifade etmesini sağlamakta ve yeni bir ortama uyumu kolaylaş̧ırmaktadır. Bu nedenle, kız çocuklarının arkadaşlarıyla olumlu iletişimi artmakta ve kız çocuklar sosyal davranışları daha fazla sergileyebilmektedirler. Kız ve erkek çocukların biyolojik farklılıklarının (Diener ve Kim, 2004) yanı sıra erkek çocukların karşısındakiyle iletişime geçmekte problem yaşaması, çevrenin erkek çocuklarının saldırgan davranışlarına daha hoşgörülü yaklaşmaları, erkek çocukların filmlerde izledikleri şiddet eğilimli karakterlerle daha fazla özdeşim kurmaları, erkek çocukların kız çocuklarına göre daha az sosyal davranışlar sergilemelerine ve daha fazla saldırgan davranışlara yönelmelerine neden olmaktadır (Altay ve Güre, 2012; Aral ve diğ., 2004; Chen ve Jiang, 2002; Kanlıkıllıçer, 2005). Farklı araştırma sonuçları ve ilgili alanyazın ile desteklenen bu araştırma sonuçları değerlendirildiğinde, kız çocukların erkek çocuklarına göre daha olumlu sosyal davranışları sergiledikleri, erkek çocukların ise saldırgan davranışları daha sık sergiledikleri görülmektedir. Dolayısıyla, kız çocukların arkadaşlarıyla işbirliği yapma, dinleme ve empati kurma, bulunduğu ortama daha kolay uyum sağlama, paylaşma, yardımlaşma gibi davranışları, erkek çocukların ise şiddet, kızgınlık veya saldırganlık içeren davranışları daha çok sergiledikleri söylenebilir.

Araştırmada, okul öncesi eğitim kurumlarına devam eden çocukların sosyal yetkinlik, anksiyete-içedönüklük ve kızgınlık-saldırganlık davranışlarının yaş değişkenine göre anlamlı düzeyde farklılaşmadı̆̆ı sonucuna ulaşılmıştır. Kargı ve Erkan (2004) yaptıkları çalışmada, beş yaşındaki çocukların dört yaşındaki çocuklara göre problemli davranışları daha fazla sergiledikleri sonucuna ulaşmışlardır. Alisinanoğlu ve Kesicioğlu (2010) yaptıkları çalışmada, çocukların saldırganlık puanlarında yaşa göre anlamlı bir farklılık olmamasına karşın aşırı hareketli olmak boyutunda dört yaş çocuklarının ortalamalarının beş yaşındaki çocuklara göre daha yüksek olduğunu belirlemişlerdir. Sarı (2007) yaptığı çalışmada, çocukların yaşı azaldıkça sosyal uyumsuzluğun arttı̆̆ı sonucuna ulaşmıştır. Rydel ve diğerleri (2005) yaptıkları çalışmada, altı yaşındaki çocukların beş yaşındaki çocuklardan daha sosyal davranışlar sergiledikleri sonucuna ulaşmıştır. Vahedi, Farrokhi ve Farajian (2012) 
yaptıkları çalışmada, çocuğun yaşı ilerledikçe sosyal yeterliliklerinde artış olduğunu, davranış sorunlarında azalma olduğunu belirlemişlerdir. Yaş değişkenine göre sosyal davranışların incelendiği çalışmaların çoğunda, problemli davranış ve saldırganlık boyutlarında yaşa göre anlamlı farklılık olduğu sonucuna ulaşılmıştır. Yaşın artmasıyla gelişen dil ve bilişsel gelişim doğrultusunda çocuğun kendini daha iyi ifade edebilmesi, karşılaştı̆ı problem durumlarına çözüm üretebilmesi çocuğun sosyal davranışlarını artırırken saldırganlık davranışlarını azaltmaktadır (Berk, 2013). Üç yaşından itibaren çocuğun çevresiyle sosyal etkileşime girme eğilimlerinin artmasıyla çocuk daha sık sosyal davranışları sergilemeye başlamaktadır. Okul öncesi eğitimle birlikte ise sosyalleşme eğiliminde olan çocukların sosyal becerileri desteklenerek kendini ifade edebilme ve davranışlarını kontrol edebilme becerileri gelişmektedir (Zembat, 2013). Fakat alanyazından farklı olarak bu çalışmada, çocukların sosyal yetkinlik, anksiyete-içedönüklük ve kızgınlık-saldırganlık davranışlarının yaş değişkenine göre anlamlı düzeyde farklılaşmadığının belirlenmesi dikkat çekici bir sonuç olarak değerlendirilebilir. Okul öncesi eğitim kurumlarına devam eden çocukların sosyal yetkinlik davranışlarının incelendiği bu araştırma sonuçları değerlendirildiğinde, farklı yaş grubundaki çocukların benzer sosyal davranışları sergiledikleri söylenebilir. Bu durumun örneklemde yaş gruplarının eşit dağılmamasından kaynaklandığı düşünülebilir.

Araştırmada, okul öncesi eğitim kurumlarına devam eden çocukların sosyal yetkinlik ve kızgınlık-saldırganlık davranışlarının kardeş sayısına göre anlamlı düzeyde farklılaşmadığı, fakat aksiyete-içedönüklük boyutunda üç ve üzeri kardeşi olan çocukların ortalamalarının kardeşi olmayan ve bir kardeşi olan çocuklardan daha yüksek olduğu belirlenmiştir. Alanyazında bu araştırma sonuçlarıyla benzer ve farklı sonuçlara ulaşan çalışmalar bulunmaktadır. Şehirli (2007) okul öncesi çocuklarının davranışlarını incelediği çalışmasında, tek çocuk olanların iki kardeşe sahip olan çocuklara kıyasla sosyal uyumlarının daha fazla olduğunu ayrıca üç kardeş ve üzeri olan çocukların ise tek çocuk olanlara göre daha fazla sosyal kayg1 gösterdiklerini ve istenmeyen davranışları daha fazla sergilediklerini ortaya koymuştur. Bu araştırmadan farklı olarak, alanyazında birçok çalışmada (Elibol Gültekin, 2008; Keçecioğlu, 2015; Nalbant, 2016; Özbey ve Alisinanoğlu, 2009) çocukların sosyal yetkinlik davranışlarının veya sosyal becerilerinin kardeş sayısına göre anlamlı düzeyde farklılaşmadığı sonucuna ulaşılmıştır. Alanyazın incelendiğinde, kardeşi olan çocukların daha fazla paylaşma ve işbirliğinde bulundukları, daha fazla sosyal iletişime girdiklerinden dolayı kardeş sayısı arttıkça çocuğun sosyal davranışlarııın da artması beklenmektedir (Nalbant, 2016). Öte yandan, ailedeki çocuk sayısının artmasıyla ebeveynin her çocukla ilgilenme süresinin azalması, kardeşler arası kıskançlık, rekabetin artması çocukların içselleştirilmiş ve dışsallaştırılmış davranış problemlerini artırmaktadır (Seven, 2006; Şehirli, 2007). Bu araştırma sonuçları değerlendirildiğinde, kardeş sayısına göre çocuğun sosyal yetkinlik ve kızgınlık-saldırganlık davranışlarının farklılaşmadığı, üç ve üzeri kardeşi olan çocukların ise anksiyete-içedönüklük puanlarının daha fazla olduğu görülmektedir. Dolayısıyla, kardeş sayısının artmasıyla yaşanan kardeşler arası çatışmaların artması, ebeveynlerin her çocuğun gelişimsel ihtiyaçlarını anında karşılamasının zorlaşması çocuğun daha fazla sosyal kaygı duymasına ve anksiyete-içedönüklük davranışlarını daha fazla sergilemelerine neden olabileceği söylenebilir.

Araştırmada, okul öncesi eğitim kurumlarına devam eden çocukların sosyal yetkinlik puanlarının anne eğitim düzeyine göre anlamlı düzeyde farklılaştı̆̆ 1 sonucuna ulaşılmıştır. Sosyal yetkinlik alt boyutunda annesi üniversite mezunu olan çocukların sosyal yetkinlik ortalamalarının daha yüksek olduğu, kızgınlık-saldırganlık ve anksiyete-içedönüklük alt boyutlarında ise annesi okur-yazar olmayan çocukların puanlarının daha yüksek olduğu belirlenmiştir. $\mathrm{Bu}$ araştırma sonuçları alanyazındaki benzer araştırma sonuçlarıyla örtüşmektedir. Günindi (2008), Arı ve Seçer (2004), Ogelman ve Topaloğlu (2012) yaptıkları çalı̧̧ada, çocukların sosyal yetkinlik davranışlarının ve sosyal uyum becerilerinin anne eğitim düzeyi ile doğru orantılı olduğunu ortaya koymuşlardır. Benzer şekilde, Keçecioğlu (2015) yaptığı çalışmada, MEB programına göre eğitim alan çocukların sosyal beceri ve problem davranışlarının anne eğitim düzeyine göre farklılaştı̆̆ını belirlemiştir. $\mathrm{Bu}$ araştırmadan farklı olarak Nalbant (2016), Alisinanoğlu ve Kesicioğlu (2010) yaptıkları çalışmada, çocukların sosyal yetkinlik davranışlarının anne eğitim düzeyine göre farklılaşmadığı sonucuna ulaşmıştır. Araştırma sonuçları incelendiğinde, genel olarak anne eğitim düzeyi yükseldikçe çocukların sosyal yetkinlik davranışlarını sergileme sıklığının arttığı buna karşın anksiyete, saldırganlık, sosyal kaygı gibi davranış problemlerinin ise azaldığı görülmektedir. Alanyazında anne eğitim düzeyi yükseldikçe annelerin çocuğun gelişimiyle ilgili bilgileri, yaşanan çatışma ve problem durumlarına çözüm odaklı yaklaşma eğilimleri, empati kurma, çocukla olumlu iletişime geçme davranışlarının da arttığı ifade edilmektedir (Topaloğlu, 2013). Bu durumda, annenin eğitim düzeyinin yükselmesiyle çocukla iletişimde daha doğru tutum sergilemesi, duygularını daha kolay ifade edebilmesi, çocuğun kendi duygularını anlama, ifade etme, empati kurma becerilerini de artırmakta ve çocuk karşılaştığı sorunlara daha kolay ve doğru çözümler üretmektedir. Böylece problem çözme ve sosyal becerileri gelişen çocuğun sosyal yetkinlik davranışlarını sergileme sıklı̆̆ının artacağı, buna karşın sosyal kaygı, saldırganlık, içe dönüklük davranışlarının ise azalacağı söylenebilir.

Araştırmada, çocukların sosyal yetkinlik davranışlarının baba eğitim düzeyine göre anlamlı düzeyde farklılaştı̆̆ sonucuna ulaşılmıştır. Sosyal yetkinlik alt boyutunda babası üniversite mezunu çocukların babası ilkokul mezunu çocuklardan sosyal yetkinlik davranışlarını daha fazla sergiledikleri belirlenmiştir. Alanyazında bu 
araştırma sonuçlarıyla benzer ve farklı sonuçlar ortaya koyan çalışmalar bulunmaktadır. Bu araştırma sonuçlarına paralel olarak, Ogelman ve Topaloğlu (2014) yaptıkları çalışmada, babası üniversite mezunu olan çocukların babası ilkokul mezunu olan çocuklara kıyasla sosyal yetkinlik davranışlarını daha fazla sergilediklerini ortaya koymuştur. Benzer şekilde, Keçecioğlu (2015) yaptığı çalışmada, baba eğitim düzeyi yükseldikçe çocukların işbirliği, kendini ifade etme ve özdenetim becerilerinin de arttığını belirlemiştir. Gülay (2008) çalışmasında, baba eğitim düzeyinin çocukların kızgınlık-saldırganlık ve anksiyete-içedönüklük davranışları üzerinde bir etkisinin olmadığını buna karşın baba eğitim düzeyi yüksek olan çocukların akranları tarafindan daha çok tercih edildiklerini ortaya koymuştur. Özbey ve Alisinanoğlu (2009) yaptığı çalışmada, babası ilkokul ve lisansüstü mezun olan çocukların içe yönelim problem davranışlarının daha yüksek olduğunu belirlemiştir. Bu araştırmadan farklı olarak Nalbant (2016), Alisinanoğlu ve Kesicioğlu (2010) yaptıkları çalışmada, çocukların sosyal yetkinlik davranışlarının ve davranış problemlerinin baba eğitim düzeyine göre değişmediğini belirlemişlerdir. Araştırma sonuçları incelendiğinde, genel olarak baba eğitim düzeyi yükseldikçe çocukların sosyal yetkinlik davranışlarını arttığı söylenebilir. Alanyazında baba eğitim düzeyi yükseldikçe babanın çocuk yetiştirme tutumlarında değişikliklerin olduğu, geleneksel anlayıştan uzaklaştığı, çocuk gelişimi ve eğitimindeki bilgisinin arttığı vurgulanmaktadır (Ogelman ve Topaloğlu, 2014). Dolayısıyla, babanın çocuk eğitiminde önemli bir role sahip olduğunun farkına varması çocuğuyla etkileşimini, birlikte farklı etkinliklere katılıp nitelikli vakit geçirme isteğini artırdığı düşünülmektedir. Böylece babanın çocuğun gelişiminde anneyle birlikte sorumluluğu paylaşması, çocukla olumlu iletişim kurması, çocuğun sosyal yetkinlik davranışlarının artmasını sağladığı söylenebilir.

Araştırmada çocukların sosyal yetkinlik davranışlarının ailenin gelir düzeyine göre anlamlı düzeyde farklılaşmadığı sonucuna ulaşılmıştır. Bu araştırma sonucuyla benzer ve farklı sonuçlara ulaşan çalışmalar bulunmaktadır. Bu araştırma sonuçlarına paralel olarak, Nalbant (2016) yaptığı çalışmada, çocukların sosyal yetkinlik puanlarının aile gelirine göre değişmediğini belirlemiştir. Bu araştırmadan farklı olarak, Çorapçı ve diğerleri (2010) yaptıkları çalışmada, yüksek gelirli ailelerin çocuklarının sosyal yetkinlik davranış puanlarının daha yüksek olduğu sonucuna ulaşmışlardır. Keçecioğlu (2015) yaptığı çalışmada, çocukların davranış problemleri toplam puanında, işbirliği ve özdenetim boyutlarının aile gelir düzeyine göre farklılaşmadığı, kendini ifade etme boyutunda ise yüksek gelirli aileye sahip olan çocukların ortalamalarının daha yüksek olduğu sonucuna ulaşmıştır. $\mathrm{Bu}$ araştırma sonuçları değerlendirildiğinde, çocukların sosyal yetkinlik davranışları üzerinde aile gelir düzeyinin belirleyici olmadığı, farklı gelir düzeyindeki ailelerin çocuklarının benzer sosyal yetkinlik davranışlarını gösterebileceği söylenebilir.

Araştırmadan elde edilen sonuçlar doğrultusunda aşağıdaki öneriler sunulmuştur:

a) Araştırma sonucunda çocukların sosyal yetkinlik davranışlarını yüksek düzeyde sergiledikleri, fakat erkek çocukların kız çocuklarına göre kızgınlık-saldırganlık davranışlarını daha fazla sergiledikleri belirlenmiştir. Okul öncesi eğitimin çocuğun tüm gelişim alanlarında kritik öneme sahip olduğu düşünüldüğünde, öğretmenlere büyük sorumluluk düşmektedir. Öğretmenlerin problem davranışları sıklıkla sergileyen çocukları tespit edip çocukların sosyal gelişimlerini olumlu yönde etkileyecek etkinliklere daha sık yer vermeleri önerilebilir. Ayrıca, etkili seminerler aracılı̆̆ıyla öğretmenlerin bu konuda daha bilinçli olması sağlanabilir.

b) Araştırma sonucunda, anne-baba eğitim düzeyi yükseldikçe çocuğun sosyal yetkinlik davranışlarının arttığı belirlenmiştir. Ailelerin çocuklarıyla etkili iletişim kurabilmeleri için halk eğitim bünyesinde kursların açılması veya ebeveynlere yönelik seminerlerin düzenlenmesi önerilebilir. Ayrıca, okul öncesi eğitim kurumlarında aile katılımının artırılması ve ailelerin çocuğun öğretmeniyle işbirliği içinde olması, çocuğun okulda kazandığı sosyal becerilerin evde de pekiştirilerek kalıcı hale gelmesini sağlayabilir.

c) Sadece erkek çocuklarıyla çalışmalar yapılarak kızgınlık-saldırganlık davranışlarını gösterme sıklıklarının nedenleri detaylı olarak incelenebilir.

d) Okul öncesi eğitim programının veya öğretmenlerin çocukla olan iletişiminin çocuğun sosyal yetkinlik davranışları üzerindeki etkisini inceleyen çalışmalar yapılabilir. 


\section{Kaynakça/References}

Akbaş, A. ve Budak, E. (2011). Okul öncesi çocuğunun gelişimi ve eğitimi. İstanbul: İdeal Yayınları.

Alisinanoğlu, F. ve Kesicioğlu, O. S. (2010). Okul öncesi dönem çocuklarının davranış sorunlarının çeşitli değişkenler açısından incelenmesi (Giresun ili örneği). Kuramsal Ĕ̆itim Bilimleri Dergisi, 3(1), 93-110.

Altay, F. B. ve Güre, A. (2012). Okul öncesi kuruma (devlet-özel) devam eden çocukların sosyal yeterlik ve olumlu sosyal davranışları ile annelerinin ebeveynlik stilleri arasındaki ilişkiler. Kuram ve Uygulamada Eğitim Bilimleri, 12(4), 2699-2718.

Andı, F. T. (2014). Okul öncesi çocuklarda ögretmen tarafindan ölçülen sosyal davranış denetimi, sosyal uyum ve sosyal yeterlilik düzeylerinin, ebeveyn çocuk yetiştirme tutumlarl ile iliş̧kisinin incelenmesi (Yüksek lisans tezi). Haliç Üniversitesi, Sosyal Bilimler Enstitüsü, İstanbul.

Aral, N., Ayhan, B. A. ve Türkmenler, B. (2004). İlköğretim okullarının sekizinci sınıflarına devam eden çocukların saldırganlık eğilimlerinin incelenmesi. Çağdaş̧ Eğitim Dergisi, 29(315), 17-75.

Arı, R. ve Seçer, Z. (2004). Farklı ana baba tutumlarının çocukların psiko-sosyal temelli problem çözme becerilerine etkisinin incelenmesi. Selçuk Üniversitesi Sosyal Bilimler Enstitüsü Dergisi, 10, 451-463.

Aunola, K., \& Nurmi, J. E. (2005). The role of parenting styles in children's problem behavior. Child Development, 76(6), 1144-1159. doi:10.1111/j.1467-8624.2005.00841.x

Avcıoğlu, H. (2003). Okul öncesi dönemdeki çocuklara sosyal becerilerin öğretilmesinde işbirlikçi öğrenme yöntemi ile sunulan öğretim programının etkililiğinin incelenmesi. OMEP Dünya Konsey Toplantısı ve Konferanst, 5(11).

Aydın, H. B. (2004). Çocuk ruh sağlı̆̆g. İstanbul: Morpa Kültür Yayınları.

Aypay, A., Çekiç, O. ve Seçkin, M. (2012). Öğretim elemanlarının öğretime ilişkin görüşlerinin normatif açısından incelenmesi. Kuram ve Uygulama Eğitim Bilimleri, 12(2), 1345-1366.

Baltaş, A. (2002). Stresle başa çımma yolları. İstanbul: Remzi Kitabevi.

Berk, L. E. (2013). Bebeklik ve yürüme çağında duygusal ve sosyal gelişim. (Çev. Özkaya, B.T.). Ankara: Nobel Yayın Dağıtım.

Büyüköztürk, Ş. (2013). Sosyal bilimler için veri analizi el kitabı. Ankara: Pegem Akademi.

Büyüköztürk, S., Çakmak, E., Akgün, Ö. E., Karadeniz, S. ve Demirel, F. (2016). Bilimsel araştırma yöntemleri (21. baskı). Ankara: Pegem Akademi Yayıncılık.

Chen, Q., \& Jiang, Y. (2002). Social competence and behavior problems in Chinese preschoolers. Early Education and Development, 13, 171-186. doi:10.1207/s15566935eed1302_4

Cohen, J. (1988). Statistical power analysis for the behavioral sciences (2nd edition). Hillsdale, NJ: Lawrence Erlbaum Associates.

Cohn, D. (1990). Child-mother attachment of sixyear olds and social competence at school. Child Development, 61, 152-162.

Çağdaş, A. ve Seçer, Z. (2002). Çocuk ve ergende sosyal ve ahlâk gelişimi. Ankara: Nobel Yayın Dağıtım.

Çorapçı, F., Aksan, N., Arslan-Yalçın, D. ve Yağmurlu, B. (2010). Okul öncesi dönemde duygusal, davranışsal ve sosyal uyum taramasi: Sosyal yetkinlik ve davranış değerlendirme-30 ölçeği. Çocuk ve Gençlik Ruh Să̆lı̆̆ı Dergisi, 17(2), 63-74.

Çorbacı, O. A. (2008). 6 yaş çocuklarında sosyal yeterliliğin, akran iliş̧kilerinin ve sosyal bilgi işleme sürecinin değerlendirilmesi (Yayınlanmamış doktora tezi). Ankara Üniversitesi, Eğitim Bilimleri Enstitüsü, Ankara.

Denham, S. A., Blair, K. A., Demulder, E., Levintans, J. Sawyer, K., Auerbach-Major, S., et al. (2003). Preschool emotional competence: Pathway to social competence? Child Development, 74(1), 238-256.

Diener, M. L., \& Kim, D. Y. (2004). Maternal and child predictors of preschool children's social competence. Journal of Applied Developmental Psychology, 25(1), 3-24. doi:10.1016/j.appdev. 2003.11.006

Dinçer, M. (2011). Kişilerarası iletişimde sorun çözücü bir iletişsim becerisi olarak atılganlık. Ankara: Nobel Basımevi. 
Elibol Gültekin, S. (2008). 5 yaş çocuklarının sosyal becerilerinin bazı değişkenler açısından değerlendirilmesi (Yüksek lisans tezi). Ankara Üniversitesi, Fen Bilimleri Enstitüsü, Ankara.

Fraenkel, J. R., Wallen, N. E., \& Hyun, H. H. (2012). How to design and evaluate research in education. USA: The McGraw-Hill Companies, Inc.

Gülay, H. (2008). 5-6 yaş çocuklarına yönelik akran ilişkileri ölçeklerinin geçerlik güvenirlik çalışmaları ve akran ilişkilerinin çeşitli değişkenler açısından incelenmesi (Yayınlanmamış doktora tezi). Marmara Üniversitesi, Eğitim Bilimleri Enstitüsü, İstanbul.

Günindi, N. (2008). Okul öncesi eğitim kurumlarına devam eden altı yaş çocuklarının sosyal uyum becerileri ile anne-babalarının empatik becerileri arasındaki ilişkinin incelenmesi (Yüksek lisans tezi). Gazi Üniversitesi, Eğitim Bilimleri Enstitüsü, Ankara.

Gür, Ç., Koçak, N., Demircan, A., Uslu, B. B., Şirin, N. ve Şafak, M. (2015). Okulöncesi eğitim kurumlarına devam eden 48-60 ay çocukların sosyal yetkinlik ve davranış değerlendirme durumlarının incelenmesi. Ĕ̈itim ve Bilim, 40(180), 13-23. doi:10.15390/EB.2015.4563

Gürüz, D. (2005). Kişilerarası iletişimde sorun çözücü bir iletişim becerisi olarak atılganlık, iletişime yeni yaklaşımlar (1. baskı). İzmir: Nobel Yayınevi.

Haktanır, G. (2011). Okul öncesi ĕgitime giriş. Ankara: Anı Yayıncılık.

Hammarberg, A., \& Hagekull, B. (2006). Changes in externalizing and internalizing behaviours over a schoolyear: differences between 6-year-old boys and girls. Infant and Child Development: An International Journal of Research and Practice, 15(2), 123-137. doi:10.1002/icd.444

Kanlıkılıçer, P. (2005). Okul öncesi davranış sorunları tarama ölçeği: Geçerlilik güvenilirlik çalışması (Yüksek lisans tezi). Marmara Üniversitesi, Eğitim Bilimleri Enstitüsü, İstanbul.

Karaca, N. H., Gündüz, A. ve Aral, N. (2011). Okul öncesi dönem çocuklarının sosyal davranışının incelenmesi. Kuramsal Eğitimbilim Dergisi, 4(2), 65-76.

Karasar, N. (2015). Araştırmalarda rapor hazırlama (19. baskı). Ankara: Nobel Akademik Yayıncılık.

Kargı, E. ve Erkan, S. (2004). Okul öncesi dönem çocukların davranış sorunlarının incelenmesi. Hacettepe Üniversitesi Ĕ̈itim Fakültesi Dergisi, 27, 135-144.

Keçecioğlu, Ö. (2015). MEB okul öncesi ĕgitim programı ve Montesorri yaklaşımına göre eğitim alan 5 yaş çocuklarının sosyal becerilerinin incelenmesi (Yüksek lisans tezi). Marmara Üniversitesi, Eğitim Bilimleri Enstitüsü, İstanbul.

Kuyucu Y. (2012). Duyguları anlama becerileri farklı düzeydeki çocukların (60-72 ay) akranlarına karşı gösterdikleri duygusal ve davranışsal tepkilerinin incelenmesi (Yayınlanmamış yüksek lisans tezi). Selçuk Üniversitesi, Sosyal Bilimler Enstitüsü, Konya.

La Freniere, P. J., \& Dumas, J. E. (1996). Social competence and behavior evaluation in children ages 3 to 6 years: The short form (SCBE-30). Psychological Assessment, 8, 369-377.

Miller, R. G. Jr. (1991). Simultaneous statistical inference. New York: Springer Verlog.

Nalbant, A. (2016). Okul öncesi eğitim kurumlarına devam eden 5 yaşs çocuklarının mizaç, sosyal yetkinlik özellikleri ile çaba sarf ederek kendini denetleme becerisi arasındaki ilişkinin incelenmesi (Yayınlanmamış Yüksek lisans tezi). Gazi Üniversitesi, Eğitim Bilimleri Enstitüsü, Ankara.

Ogelman, H. G. ve Topaloğlu, Z. Ç. (2014). 4-5 yaş çocuklarının sosyal yetkinlik, saldırganlık, kaygı düzeyleri ile anne-babalarının ebeveyn özyeterliği algısı arasındaki ilişkilerin incelenmesi. Abant İzzet Baysal Üniversitesi Ĕ̈itim Fakültesi Dergisi, 14(1), 241-271. doi: 10.17240/aibuefd.2014.14.1-5000091511

Özbey, S. ve Alisinanoğlu, F. (2009). Okul öncesi eğitim kurumuna devam eden 60-72 aylık çocukların problem davranışlarının bazı değişkenlere göre incelenmesi. Uluslararası Sosyal Araştırmalar Dergisi, 2(6), 493517.

Özdemir, S. (2014). 5-6 yaş grubu çocukların serbest zaman etkinliklerindeki oyun ve oyuncak tercihlerinin incelenmesi. Journal of Educational Science, 2(2), 1-15.

Özkan, H. K. ve Yaralı, K. T. (2016). Beş-altı yaş çocuklarının bilişsel stilleri ile sosyal yetkinlik ve davranış durumlarının incelenmesi. Kastamonu Education Journal, 24(5), 2195-2206. 
Pallant, J. (2005). SPSS survival manual: A step by step guide to data analysis using SPSS for windows. Australia: Australian Copyright.

Rydell, A., Bohlin, G., \& Thorell, L. B. (2005). Representations of attachment to parents and shyness as predictors of children's relationships with teachers and peer competence in preschool. Attachment ve Human Development, 7, 187-204. doi: 10.1080/14616730500134282

Sarı, E. (2007). Anasınıfina devam eden 5-6 yaş grubu çocukların, annelerinin çocuk yetiştirme tutumlarının, çocuğun sosyal uyum ve becerilerine etkisinin incelenmesi (Yayınlanmamış yüksek lisans tezi). Gazi Üniversitesi, Eğitim Bilimleri Enstitüsü, Ankara.

Seven, S. (2006). 6 yaş çocuklarının sosyal beceri düzeyleri ile bağlanma durumları arasındaki ilişkilerin incelenmesi (Yayımlanmamış doktora tezi). Gazi Üniversitesi, Eğitim Bilimleri Enstitüsü, Ankara.

Sezici, E. (2013). Okul öncesi çocuklarda oyun terapisinin sosyal yetkinlik ve davranış yönetimine etkisi (Yayımlanmamış yüksek lisans tezi). Marmara Üniversitesi, Sağlık Bilimleri Enstitüsü, İstanbul.

Şehirli, N. (2007). Çocuk davranışlarını değerlendirme ölçeği'nin gelişstirilmesi ve bazı değisşkenlere göre incelenmesi (Yayımlanmamış yüksek lisans tezi). Gazi Üniversitesi, Sosyal Bilimler Enstitüsü, Ankara.

Şendil, Ç. Ö. (2010). An investigation of social competence and behavioral problems of 5-6 year old children through peer preference (Yayımlanmamış Yüksek lisans tezi). The Graduate School Of Social Sciences, Middle East Technical University, Ankara.

Uğur, H. (1998). Anasınıfi eğitiminin sosyalleşmedeki rolü ve öğrencileri sosyalleştirme açısından özel ve devlet anasınıflarının karşılaş̧ırılması (Yayınlanmamış yüksek lisans tezi). Sakarya Üniversitesi, Sosyal Bilimler Enstitüsü, Sakarya.

Ural, O., Güven, G., Sezer, T., Azkeskin, K. ve Yılmaz, E. (2015). Okul öncesi dönemdeki çocukların bağlanma biçimleri ile sosyal yetkinlik ve duygu düzenleme becerileri arasındaki ilişkinin incelenmesi. Hacettepe Üniversitesi Sağllk Bilimleri Fakültesi Dergisi, 1, 589-598.

Ünal, S. (2007). Atılganlık becerileri eğitim programının ilkögrretim ikinci kademe öğrencilerinin atılganlı düzeyi ve benlik saygısı üzerindeki etkisi (Yayımlanmamış yüksek lisans tezi). Dokuz Eylül Üniversitesi, Eğitim Bilimleri Enstitüsü, İzmir.

Vahedi, S., Farrokhi, F., \& Farajian, F. (2012). Social competence and behavior problems in preschool children. Iranian Journal of Psychiatry, 7(3), 126.

Yalçın, H. (2010). Çocuk gelişim. Ankara: Nobel Yayınevi.

Yasankul, N. (2007). Illköğretim 4. ve 5. sınıf öğrencilerinin saldırganlık eğilimleri ile eğitim algıları arasındaki ilişkinin incelenmesi (Yayımlanmamış yüksek lisans tezi). Marmara Üniversitesi, Eğitim Bilimleri Enstitüsü, İstanbul.

Yavuzer, H. (1985). Çocuk psikolojisi. İstanbul: Altın Kitaplar Matbaası.

Zembat, R. (2013). Okul öncesinde özel ögretim yöntemleri. Ankara: Anı.Yayınc1lık. 